\title{
DEGRADASI KOMPONEN SELULOSA, HEMISELULOSA, DAN PATI TEPUNG KULIT UBI KAYU MENJADI GULA REDUKSI OLEH Aspergillus niger, Trichoderma viride, DAN Acremonium sp. IMI 383068
}

Degradation of Cellulose, Hemicellulose, and Starch Component in Cassava Peels Flour into Reducing Sugar by Aspergillus niger, Trichoderma viride, and Acremonium sp. IMI 383068

\author{
Jay Jayus ${ }^{1 *}$, Ahmad Nafi ${ }^{1)}$, Anis Shabrina Hanifa ${ }^{1)}$ \\ ${ }^{1)}$ Jurusan Teknologi Hasil Pertanian, Fakultas Teknologi Pertanian, Universitas Jember \\ Jalan Kalimantan 37, Kampus Tegal Boto Jember 68121 \\ *Korespondensi Penulis: jayus.ftp@unej.ac.id
}

\begin{abstract}
As the solid waste produced from cassava processing industry such as tapioca factory or its derivatives, the cassava peel is potential to be use as a source of reducing sugar through hydrolysis process, since the peels contains a high amount of starch and lignocellulose components. The more environmentally friendly enzymatic hydrolysis using several microorganisms will be introduced in this study as an alternative to avoid the unsafe acid hydrolysis. However, the hydrolysis process using a single microorganism is not efficient since the hydrolytic enzyme produced is limited to a single enzyme, while the component in the cassava peels to be hydrolyzed is diverse which include cellulose, lignin, hemicellulose and starch. Therefore, it is necessary to optimize the hydrolysis process by combining several microorganisms (A. niger, T. viride and Acremonium sp. IMI 383068) which produced different specificity of hydrolytic enzyme depending on the substrate available in the cassava peels. The aims of this research were to determine the effect of single and mixed culture on the amount of reducing sugar released during the simultaneous cultivation. The result showed that the use of simultaneous mixed cultures during hydrolysis process was able to produce higher reducing sugar compare to that of single culture. The hydrolysis of cassava flour using a single strain of $A$. niger, T. viride and Acremonium sp. IMI 383068 respectively produced $4.86 \mathrm{~g} / \mathrm{L}, 4.02 \mathrm{~g} / \mathrm{L}$, and 1.68 $\mathrm{g} / \mathrm{L}$ of reducing sugar, while the hydrolysis of it using simultaneous mixed cultures of A. niger, $T$. viride, and Acremonium sp. IMI 383068 produced 7.23 g/L of reducing sugar.
\end{abstract}

Keywords: cassava peels, hydrolysis, reducing sugar

\section{PENDAHULUAN}

Sebagai salah satu negara penghasil biomassa yang cukup melimpah, Indonesia banyak menghasilkan produk samping hasil pertanian seperti kulit ubi kayu, limbah padat yang dihasilkan oleh agroindustri pengolahan seperti pada industri tapioka, pengolahan keripik, dan turunannya. Menurut Artiyanti dan Soedjono (2011) kulit ubi kayu mengandung $43,63 \%$ selulosa, $36,58 \%$ hemiselulosa, 7,65\% lignin, dan 10,38\% pati. Kandungan selulosa, hemiselulosa, dan pati yang cukup tinggi pada kulit ubi kayu berpotensi untuk dijadikan sumber gula reduksi melalui proses hidrolisis. Pada proses hidrolisis, rantai panjang polisakarida akan dipecah menjadi rantai pendek atau karbohidrat sederhana melalui reaksi kimia menggunakan air (Zamora, 2005). Limbah biomassa kulit ubi kayu yang mengandung polisakarida berupa selulosa, hemiselulosa, dan pati akan dipecah menjadi karbohidrat yang lebih sederhana seperti gula reduksi.

Upaya pencarian substrat untuk produksi etanol terus dilakukan, selain penggunaan limbah yang mengandung gula sederhana seperti molasses (Jayus et al., 2016; Noorvita et al., 2016), banyak penelitian yang mengarah pada pemanfaatan limbah biomassa menjadi gula reduksi sebagai substrat pembuatan bioetanol melalui proses hidrolisis, baik 
hidrolisis asam maupun hidrolisis enzimatik. Menurut Taherzadeh dan Karimi (2007), hidrolisis enzimatik memiliki beberapa keuntungan dibandingkan dengan hidrolisis kimiawi, antara lain tidak terjadi degradasi gula hasil hidrolisis, kondisi proses yang lebih lunak (suhu rendah, $\mathrm{pH}$ netral), berpotensi memberikan hasil yang tinggi, dan biaya pemeliharaan yang relatif rendah karena tidak ada bahan yang korosif. Hidrolisis secara enzimatik dapat dilakukan menggunakan enzim atau mikroorganisme yang dapat menghidrolisis polisakarida menjadi monomer sederhana seperti gula reduksi. Jenis mikroorganisme yang dapat digunakan dalam proses hidrolisis enzimatik dari limbah biomassa menjadi gula reduksi adalah kapang. Faiqoh (2016) melaporkan bahwa penggunaan kapang $A$. niger dan $T$. viride secara bersamaan dalam menghidrolisis substrat tepung kulit ubi kayu dapat meningkatkan kadar gula reduksi. Penggunaan kultur campuran $A$. niger dan $T$. viride secara bersamaan juga mampu menghasilkan gula reduksi lebih tinggi sebagai substrat pembuatan bioetanol dari tepung kulit ubi kayu (Jayus et al., 2017). Acremonium sp. IMI 383068 diduga dapat dijadikan sebagai pendegradasi tepung kulit ubi kayu karena kemampuannya memproduksi enzim $(1,6)$ ß-glukanase (Jayus et al., 2001) dan (1,3)ß-glukanase (Jayus et al., 2004).

Kendala yang dihadapi dalam proses hidrolisis enzimatik menggunakan bantuan mikroorganisme adalah kemampuan mikroorganisme yang masih rendah dalam mendegradasi komponen selulosa, hemiselulosa, dan pati sehingga proses hidrolisisnya tidak efisien. Oleh karena itu perlu adanya kajian mengenai pengaruh kombinasi penggunaan kultur campuran pada proses hidrolisis untuk mengetahui apakah penggunaan kultur tunggal dan kultur campuran berpengaruh terhadap gula reduksi yang dihasilkan.

\section{METODE PENELITIAN}

\section{Alat dan Bahan}

Alat penelitian yang digunakan yaitu shaking incubator (WIS-20R-Berlin), inkubator (Scientific Series 2000-Jerman), laminar air flow (Crumair Model 9005 FL-Espana), autoklav (SA 300VL-Japan), refrigerated macrocentrifuge (Model-2-16 kl-Jerman), spektrofotometer (Genesys 10 UV VIS-China), colony counter (Funke Gerber-UK), oven (Memmert-Jerman), Blender (National), ayakan Tyler 100 mesh, digital $\mathrm{pH}$ meter, dan glasswere penelitian. Bahan baku dalam penelitian yaitu kulit ubi kayu yang diperoleh dari UKM pengolahan keripik singkong di Desa Baratan-Jember, $\mathrm{NaOCl}$ (CV. LUMADA bitha SUKSES), mineral salt solution (merck), yeast extract (merck), asam sitrat (merck), $\mathrm{NaOH}$ (merck), Malt Extrat Agar (merck), $\mathrm{NaCl}$ (merck), dietil eter (merck), alkohol (one med), $\mathrm{HCl}$ (merck), reagen dinitrosalisilic acid (DNS) (himedia), fenol (merck), $\mathrm{H}_{2} \mathrm{SO}_{4}$ (merck). Kultur mikrorganisme yang digunakan adalah kapang A. niger, $T$. viride yang diperoleh dari Laboratorium Mikrobiologi Pangan dan Hasil Pertanian Fakultas Teknologi Pertanian, dan Acremonium sp. IMI 383068 yang diperoleh dari Laboratorium Center for Development Advanced Science and Technology (CDAST) Universitas Jember.

\section{Tahapan Penelitian}

\section{Pembuatan tepung kulit ubi kayu}

Kulit ubi kayu segar yang diperoleh dari UKM pengolahan keripik singkong di Desa Baratan-Jember dibersihkan kulit terluarnya yang berwarna coklat dan dilakukan pencucian hingga bersih. Kulit ubi kayu yang telah bersih kemudian dilakukan pengeringan menggunakan sinar matahari selama \pm 2 hari. Selanjutnya kulit ubi kayu yang telah kering dilakukan pengecilan ukuran menggunakan blender dan dilakukan pengayakan menggunakan ayakan dengan ukuran 100 mesh. 


\section{Delignifikasi tepung kulit ubi kayu}

Delignifikasi dilakukan secara kimia dengan menggunakan larutan $\mathrm{NaOCl}$ berdasarkan metode Assadam (2014) dengan merendam $1000 \mathrm{~g}$ tepung kulit ubi kayu dalam 10 L larutan $\mathrm{NaOCl} 1 \%$ selama 5 jam pada suhu $28^{\circ} \mathrm{C}$. Setelah itu dilakukan pengendapan untuk diambil padatannya. Endapan yang terbentuk dicuci menggunakan aquades hingga netral ( $\mathrm{pH}$ 7). Tepung kulit ubi kayu yang telah didelignifikasi kemudian dianalisis kadar air, kadar pati, dan kadar lignoselulosanya.

\section{Proses hidrolisis}

Kulit ubi kayu terdelignifikasi sebanyak 2\% (w/v) ditambah nutrisi untuk mengkondisikan mikroorganisme tumbuh optimal yaitu berupa $0.3 \mathrm{~g} / \mathrm{L}$ yeast extract dan $50 \mathrm{~mL} / \mathrm{L}$ mineral salts solution, dan dilakukan pengaturan $\mathrm{pH} 5$, kemudian disterilisasi pada $121^{\circ} \mathrm{C}$ selama 15 menit. Setelah itu media didinginkan dan diinokulasi dengan kultur tunggal kapang A. niger, $T$. viride dan Acremonium sp. IMI 383068 dan kultur campuran dari ke 3 kapang tersebut sebanyak $10 \% \quad(\mathrm{v} / \mathrm{v})$. Setelah itu diinkubasi dalam shaking incubator pada suhu $30^{\circ} \mathrm{C}$ dengan kecepatan $150 \mathrm{rpm}$ selama 60 jam dan dilakukan pengamatan populasi mikroba dan kadar gula reduksi secara periodik setiap 12 jam sekali.

\section{Metode Analisis}

Parameter pengamatan dilakukan pada dua bagian, yaitu pada tepung kulit ubi kayu dan hidrolisat kulit ubi kayu.
Parameter pengamatan pada bahan baku tepung kulit ubi kayu meliputi kadar air (Sudarmadji et al., 1997), kadar pati (Sudarmadji et al., 1997), dan kadar lignoselulosa (Datta, 1981). Selanjutnya, pengamatan populasi mikroba (Ristiati, 2000) pada suspensi hasil hidrolisis. Suspensi yang dihasilkan kemudian dipisahkan menggunakan refrigerated macrocentrifuge untuk diambil filtratnya dan dilakukan analisis kadar total gula terlarut (Dubois et al., 1956), dan gula reduksi (Miller, 1959). Perhitungan efisiensi hidrolisis (Thalagala et al., 2009) dilakukan pada semua hidrolisat yang dihasilkan.

\section{HASIL DAN PEMBAHASAN}

\section{Komposisi Kimia Tepung Kulit Ubi Kayu}

Bahan baku utama tepung kulit ubi kayu yang akan dihidrolisis sebelumnya diberi perlakuan delignifikasi untuk mengurangi kandungan lignin. Karakteristik tepung kulit ubi kayu yang digunakan pada penelitian ini sebagai substrat hidrolisis untuk menghasilkan gula reduksi ditunjukkan pada Tabel 1.

Tepung kulit ubi kayu yang digunakan sebagai substrat hidrolisis untuk menghasilkan gula reduksi memiliki kadar air sebesar $10,88 \%$ (b/b) (Tabel 1). Menurut Loebis (2008) kadar air bahan baku dijaga agar tidak meningkat sehingga tidak terjadi penurunan porositas dan laju difusi oksigen yang dapat meyebabkan perpindahan panas dan massa berlangsung

Tabel 1. Komposisi kimia tepung kulit ubi kayu

\begin{tabular}{lcc}
\hline & \multicolumn{2}{c}{ Perlakuan (\%) } \\
\cline { 2 - 3 } Komponen & $\begin{array}{c}\text { Tepung kulit ubi kayu tanpa } \\
\text { delignifikasi }\end{array}$ & $\begin{array}{c}\text { Tepung kulit ubi kayu setelah } \\
\text { delignifikasi }\end{array}$ \\
\hline Kadar air & $12,09 \pm 0,15$ & $10,88 \pm 0,14$ \\
Kadar pati & $20,92 \pm 0,57$ & $11,55 \pm 0,66$ \\
Kadar lignin & $8,47 \pm 0,15$ & $3,04 \pm 0,12$ \\
Kadar selulosa & $32,15 \pm 0,57$ & $51,19 \pm 0,63$ \\
Kadar hemiselulosa & $19,15 \pm 0,83$ & $16,93 \pm 0,60$ \\
\hline
\end{tabular}


kurang baik. Kondisi tersebut akan mempengaruhi pertumbuhan miselium kapang dan aktivitas enzim. Sebelum digunakan untuk hidrolisis, tepung kulit ubi kayu terlebih dahulu diberi perlakuan pretreatment berupa delignifikasi menggunakan larutan $\mathrm{NaOCl}$ dengan konsentrasi $1 \%$. Delignifikasi diperlukan untuk mengurangi kadar lignin, menurunkan tingkat kristalin selulosa dan meningkatkan porositas material (Sanchzes dan Cardona, 2008; Hsu et al., 2010).

Delignifikasi tepung kulit ubi kayu menunjukkan telah terjadi penurunan kadar hemiselulosa dari $19,15 \%$ menjadi $16,93 \%$, kadar lignin dari $8,47 \%$ menjadi $3,04 \%$, dan penurunan kadar pati dari $20,19 \%$ menjadi $11,55 \%$. Hilangnya hemiselulosa, lignin, dan pati mengakibatkan persentase selulosa tepung kulit ubi kayu meningkat dari 32,15\% menjadi 51,19\% (Tabel 1). Dari hasil yang diperoleh menunjukkan bahwa adanya proses delignifikasi dapat mengurangi kadar lignin, kadar hemiselulosa, dan kadar pati sehingga meningkatkan kadar selulosa. Penelitian yang dilakukan oleh Assadam (2014) melaporkan bahwa struktur serat selulosa pada kulit kopi kering lebih berpori setelah delignifikasi menggunakan larutan $\mathrm{NaOCl} 1 \%$.

Ruriani et al. (2012) juga mengindikasikan bahwa delignifikasi menggunakan $\mathrm{NaOCl} 1 \%$ selama 5 jam mampu mengubah struktur selulosa menjadi lebih amorf. Selain menurunkan kadar lignin dan pati, proses delignifikasi juga mampu munurunkan kadar hemiselulosa pada tepung kulit ubi kayu. Menurut Ibrahim (1998) hemiselulosa mempunyai rantai polimer yang pendek dan tak berbentuk sehingga sebagian besar dapat larut dalam air.
Profil Hidrolisis Kultur Tunggal dan Kultur Campuran Kapang A. niger, T. viride, dan Acremonium sp. IMI 383068

Penggunaan kultur campuran dapat meningkatkan hasil gula reduksi lebih tinggi dibandingkan dengan penggunaan kultur tunggal. Hidrolisis oleh kultur kapang A. niger, $T$. viride, dan Acremonium sp. IMI 383068 dengan perlakuan perbedaan penggunaan kultur tunggal dan kultur campuran ditunjukkan pada Gambar 1.

Gambar 1 menunjukkan bahwa hasil pengamatan populasi kapang pada 0 jam rata-rata sebanyak $1 \times 10^{6} \mathrm{CFU} / \mathrm{mL}$ menghasilkan gula reduksi sebesar 0,26 g/L. Populasi maksimum kapang dan gula reduksi berada pada waktu hidrolisis 48 jam pada semua perlakuan. Populasi maksimum hidrolisis menggunakan kultur tuggal A. niger sebesar 9x10 $\mathrm{CFU} / \mathrm{mL}$ menghasilkan gula reduksi sebesar $4,86 \mathrm{~g} / \mathrm{L}$ (Gambar 1a), hidrolisis menggunakan kultur tunggal $T$. viride sebesar $10 \times 10^{6} \mathrm{CFU} / \mathrm{mL}$ menghasilkan gula reduksi sebesar $4,02 \mathrm{~g} / \mathrm{L}$ (Gambar 1b), hidrolisis menggunakan kultur tunggal Acremonium sp. IMI 383068 sebesar $4 \times 10^{6} \quad \mathrm{CFU} / \mathrm{mL}$ menghasilkan gula reduksi sebesar 1,68 g/L (Gambar 1c), sedangkan hidrolisis menggunakan kultur campuran A. niger, $T$. viride, dan Acremonium sp. IMI 383068 sebesar $16 \times 10^{6} \mathrm{CFU} / \mathrm{mL}$ menghasilkan gula reduksi sebesar 7,23 $\mathrm{g} / \mathrm{L}$ (Gambar 1d). 


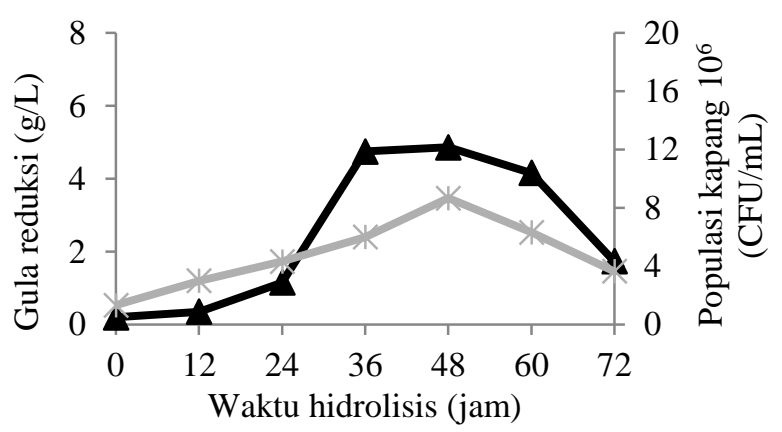

(a)

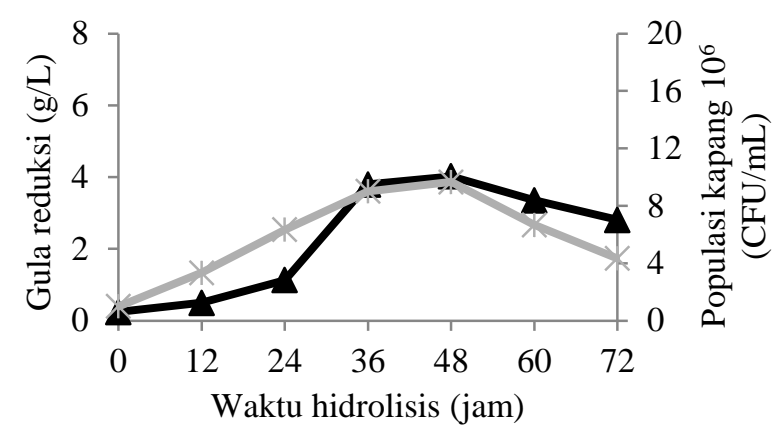

(b)

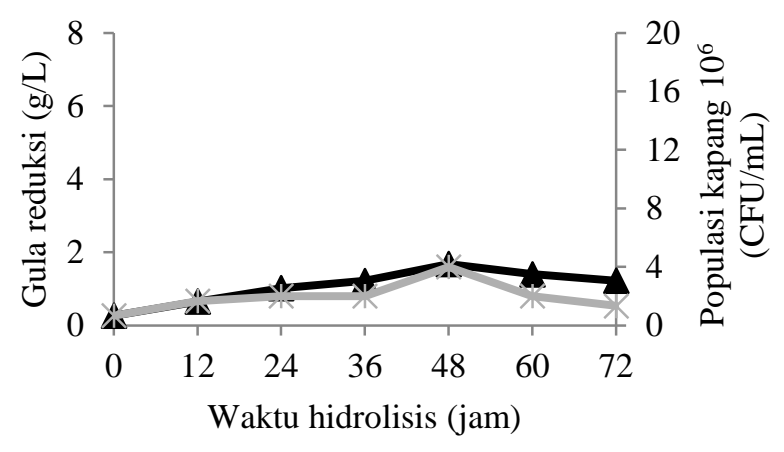

(c)

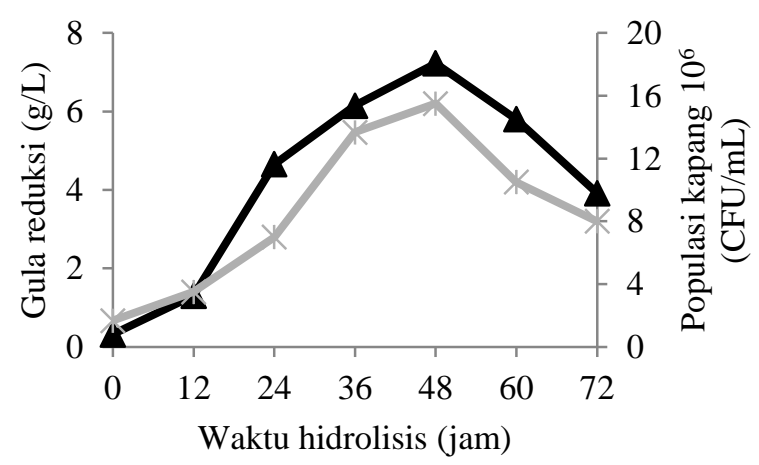

(d)

Gambar 1. Perubahan kadar gula reduksi ( dan populasi mikroba ( $\rightarrow$ ) pada kultur tunggal A. niger (a), T. viride (b), Acremonium sp. IMI 383068 (c), dan kultur campuran A. niger, $T$. viride, Acremonium sp. IMI 383068 (d)
Kapang $A$. niger mampu menghasilkan enzim amilolitik berupa amilase (Fowler, 1988) yang dapat mendegradasi pati dan selulase (Fowler, 1988) yang dapat mendegradasi selulosa, serta menghasilkan xylanase (Villena et al., 2007) yang dapat mendegradasi xylan (hemiselulosa). Kapang T. viride menghasilkan selulase berupa endo- $\beta$-1,4glukanase, ekso- $\beta$-1,4-glukanase, dan $\beta$ 1,4-glukosidase (Crueger dan Crueger, 1982) yang dapat mendegradasi komponen selulosa; dan menghasilkan endo- $\beta-1,4-$ xylanase (Ujiie et al., 1991) yang mampu mendegradasi xylan (hemiselulosa). Kapang Acremonium sp. IMI 383068 menghasilkan enzim $\beta$-1,3-glukanase dan $\beta$-1,6-glukanase (Jayus et al., 2001 \& 2004) dan sebagian besar Acremonium sp. dapat menghasilkan enzim selulase (Astutik et al., 2007). Enzim-enzim inilah yang bersinergi menghidrolisis komponen polisakarida dalam tepung kulit ubi kayu. Gambar 1 menunjukkan adanya kecenderungan kadar gula reduksi yang meningkat dengan penggunaan kultur campuran dari tiga jenis kapang dibandingkan dengan penggunaan kutur tunggal. Penggunaan kultur campuran dalam proses hidrolisis mampu menghasilkan enzim yang lebih kompleks dibandingkan dengan hidrolisis menggunakan kultur tunggal.

Campuran enzim yang dihasilkan
dari beberapa kapang mampu memperbaiki kerja endo- dan eksoglukanase, serta glukosidase menjadi lebih seimbang untuk mendegradasi selulosa (Anwar, 2010). Demikian juga xylanase dapat mendegradasi xylan (hemiselulosa) serta enzim amilolitik berupa amilase mampu mendegradasi pati sehingga gula reduksi yang dihasilkan jauh lebih tinggi dibandingkan dengan penggunaan kultur tunggal dalam proses hidrolisis. 
Tabel 2. Efisiensi hidrolisis pada pengamatan ke-48 jam

\begin{tabular}{lccc}
\hline Perlakuan & $\begin{array}{c}\text { Kadar gula reduksi } \\
(\mathrm{g} / \mathrm{L})\end{array}$ & $\begin{array}{c}\text { Kadar selulosa }+ \\
\text { hemiselulosa + pati } \\
(\mathrm{g})\end{array}$ & $\begin{array}{c}\text { Efisiensi } \\
\text { hidrolisis } \\
(\%)\end{array}$ \\
\hline Kultur A. niger & 4,86 & 15,93 & 30,51 \\
Kultur T. viride & 4,02 & 15,93 & 25,24 \\
Kultur Acremonium sp. IMI 383068 & 1,68 & 15,93 & 10,55 \\
$\begin{array}{l}\text { Kultur campuran A. niger, T. viride, } \\
\text { dan Acremonium sp. IMI 383068 }\end{array}$ & 7,23 & 15,93 & 45,39 \\
\hline
\end{tabular}

\section{Efisiensi Hidrolisis oleh Aspergillus niger, Trichoderma viride, dan Acremonium sp. IMI 353068}

Efisiensi hidrolisis diperoleh dengan cara membagi total gula terlarut dan gula reduksi yang dihasilkan selama proses hidrolisis dengan berat total selulosa, hemiselulosa, dan pati yang terkandung di dalam bahan tepung kulit ubi kayu. Efisiensi hidrolisis ditunjukkan pada Tabel 2.

Penggunaan kultur tunggal dan kultur campuran pada proses hidrolisis dari 3 jenis kapang memberikan hasil efisiensi hidrolisis yang berbeda. Hidrolisis oleh $A$. niger, $T$. viride, dan Acremonium sp. IMI 383068 selama 48 jam menghasilkan gula reduksi optimum (Tabel 2). Efisiensi hidrolisis tertinggi diperoleh dari perlakuan penggunaan kultur campuran dari 3 jenis kapang dalam satu waktu proses hidrolisis yaitu sebesar 45,39\%. Penggunaan kultur tunggal A. niger, $T$. viride, dan Acremonium sp. IMI 383068 masing-masing menghasilkan efisiensi hidrolisis secara berurutan sebesar $30,51 \%$; $25,24 \%$; dan $10,55 \%$.

Penggunaan kultur campuran kapang diduga mampu melengkapi enzim yang bekerja selama hidrolisis, sehingga komponen selulosa, hemiselulosa, dan pati yang didegradasi lebih banyak, sedangkan penggunaan kultur tunggal hanya mampu mendegradasi beberapa komponen karena enzim yang dihasilkan tidak beragam seperti pada penggunaan kultur campuran, Kenyataan ini sesuai dengan Tabel 2, yang menunjukkan apabila gula reduksi yang dihasilkan tinggi, maka efisiensi hidrolisisnya juga tinggi. Faiqoh (2016) juga melaporkan hal yang sama bahwa efisiensi hidrolisis meningkat seiring dengan meningkatnya gula reduksi yang dihasilkan.

\section{KESIMPULAN}

Hidrolisis menggunakan kultur campuran dari 3 jenis kapang A. niger, $T$. viride, dan Acremonium sp. IMI 383068 secara simultan mampu menghasilkan gula reduksi lebih tinggi dibandingkan dengan penggunaan kultur tunggal dari ketiganya. Hidrolisis menggunakan kultur tunggal $A$. niger, T. viride, dan Acremonium sp. IMI 383068 masing-masing secara berurutan menghasilkan gula reduksi sebesar 4,83; 4,02; dan 1,68 g/L, sedangkan hidrolisis menggunakan kultur campuran A. niger, $T$. viride, dan Acremonium sp. IMI 383068 secara simultan mampu menghasilkan gula reduksi sebesar 7,23 g/L. Efisiensi hidrolisis tertinggi diperoleh pada perlakuan penggunaan kultur campuran dari 3 jenis kapang yaitu sebesar $45,39 \%$.

\section{UCAPAN TERIMA KASIH}

Penelitian ini didanai oleh PT. Indofood Sukses Makmur, Tbk. melalui bantuan dana penelitian tugas akhir program Indofood Riset Nugraha tahun 2017/2018. 


\section{DAFTAR PUSTAKA}

Anwar, N. 2010. Peningkatan unjuk kerja hidrolisis enzimatik jerami padi menggunakan campuran selulase kasar dari Trichoderma ressei dan Aspergillus niger. Makara Sains. 14 (2): 113-116.

Artiyani, A., dan Soedjono, E.S. 2011. Bioetanol dari limbah kulit singkong melalui proses hidrolisis dan fermentasi dengan Saccharomyces cerevisiae. "Prosiding Seminar Nasional Manajemen Teknologi XIII" Institut Teknologi Sepuluh Nopember, Surabaya.

Assadam, A. 2014. "Delignifikasi Secara Kimia Kopi Robusta Hasil Samping Pengolahan Kopi Metode Kering Sebagai Substrat Bioetanol”. Skripsi. Fakultas Teknologi Pertanian Universitas Jember, Jember.

Astutik, R. P., Kuswytasari, N.D., dan Shovitri, M. 2007. Uji Aktivitas Enzim Selulase dan Xylanase Isolate Kapang Tanah Wonorejo, Surabaya. Paper. Jurusan Biologi Fakultas Matematika dan Ilmu Pengetahuan Alam, ITS, Surabaya.

Crueger, W, dan Crueger, A. 1982. Biotechnology. Madison: Science Tech, Inc., Madison.

Datta, R. 1981. Acidogenic fermentation of lignocellulose acid yield and convertion of components. Biotechnology and Bioengineering, 23: 2167-2170.

Dubois, M., Gilles, K.A., Hamilton, J.K., Rabers, P.A., dan Smith, F. 1956. Colometric method for determination of sugar and related substances. Analytical Chemistry, 28 (3): 350-356.

Faiqoh, H. 2016. "Efisiensi Hidrolisis Tepung Kulit Ubi Kayu Menggunakan Aspergillus niger dan Trichoderma viride". Skripsi. Fakultas Teknologi Pertanian Universitas Jember, Jember.

Fowler, M.W. 1988. "Enzyme Technology" in Biotechnology for Engineers, Biological System in Technological Processes, Edited: Scragg, A. H., John Wiley \& Sons, New York.
Hsu, T.C., Guo, G.L., Chen, W.H., dan Hwang, W.S. 2010. Effect of dilute acid pretreatment of rice straw on structural properties and enzymatic hydrolysis. Bioresource Technology, 101: 49074913.

Ibrahim, M. 1998. Clean fractination of biomassa - steam explosion and extraction. Faculty of The Virginia Polytechnic Institute and State University.

Jayus, J., McDougall, B.M., and Seviour, R.J. 2001. Purification and properties of a (1 $\rightarrow 6)$-B-glucanase from Acremonium sp. IMI 383068. Enzyme and Microbial Technology, 29: 194-200.

Jayus, J., McDougall, B.M., and Seviour, R.J. 2004. Purification and characterization of the $(1 \rightarrow 3)-\beta-$ glucanases from Acremonium sp. IMI 383068. FEMS Microbiology Letters, 230: $259-264$.

Jayus, J., Nurhayati., Mayzuhroh, A., Arindhani, S., dan Caroenchai, C. 2016. Studies on bioethanol production of commercial baker's and alcohol yeast under aerated culture using sugarcane molasses as the media. Agriculture and Agricultural Science Procedia, 9: 493499.

Jayus, J., Suwasono, S., dan Wijayanti, I. 2017. Produksi bioetanol secara SHF dan SSF menggunakan Aspergillus niger, Trichoderma viride, dan new aule instant dry yeast pada media kulit ubi kayu. Jurnal Agroteknologi, 11 (01): 61-68.

Loebis, E.H. 2008. "Optimasi Proses Hidrolisis Kimiawi dan Enzimatis Tandan Kosong Kelapa Sawit Menjadi Glukosa untuk Produksi Etanol”. Tesis. Program Pascasarjana, Institut Pertanian Bogor, Bogor.

Miller, G. L. 1959. Use of dinitrosalycilic acid reagent for determination of reducing sugar. Analysis Chemical, (31): 426428. 
Noorvita, I.V., Jayus, J., dan Nurhayati, N. 2016. Produksi bioetanol oleh Saccharomyces cerevisiae FNCC 3210 pada media molases dengan kecepatan agitasi dan aerasi yang berbeda. Jurnal Agroteknologi, 10 (02): 184-192.

Ristiati, N. P. 2000. Pengantar Mikrobiologi Umum. Proyek Pengembangan Guru Sekolah Menengah IBRD Loan No. 3979, Jakarta.

Ruriani, E., Meryandini, A., dan Sunarti, T.C. 2012. Enzymatic hydrolysis of delignified corncob using combined enzyme. International Journal of Food Nutrition and Public Health, 5: 107-127.

Sanchzes, O.O., dan Candona, C.A. 2008. Review: Trends of biotechnological production of fuel ethanol from different feedstock. Bioresource Technology, 99 (13): 5270-5295.

Sudarmadji, S., Haryono, B., dan Suhardi. 1997. Prosedur Analisa Untuk bahan Makanan dan Pertanian. Liberty, Yogyakarta.

Taherzadeh, M.J., dan Karimi, K. 2007. AcidBased Hydrolysis Prosesses for Ethanol from Lignocellulosic Materials. Isfahan University of Technology: Departement of Chemical Engineering.

Thalagala, T.A.T.P., Kodama, S., Mishima, T., Isono, N., Furujyo, A., Kawasaki, Y., dan Hisamatsu, M. 2009. Study on a new preparation od D-Glucose rich fractions from various lignocelluloses through a two-step extraction with sulphuric acid. The Japanese Society of Applied Glycoscience, 56: 1-6.

Ujiie, M., Roy, C., dan M. Yaguchi, M. 1991. Low-molecular-weight xylanase from Tricoderma viride. Applied and Environmental Mycrobiology, 57 (6): 1860-1862.

Villena, Grett, K., dan Correa, P.W. 2007. Production of lignocellulolytic enzyme by Aspergillus niger biofilms at variable water activities. Electronic Journal of Biotechnology Chile, 10 (1): 124-140.
Zamora, A. 2005. Carbohydrate - Chemical Structure.

http://www.scientificpsychic.com/fitness/ carbohydrates. [Diakses tanggal 25 Desember 2016]. 